\title{
THE INFLUENCE OF ORGANIZATIONAL CULTURE TO EMPLOYEE PERFORMANCE: A STUDY ON EMPLOYEES AT PT. BANK NEGARA INDONESIA (PERSERO), TBK MALANG BRANCH OFFICE, INDONESIA
}

\author{
Sholihah Fitri, Musadieq Mochammad Al, Aziz Aulia Luqman* \\ Faculty of Administrative Science, University of Brawijaya, Indonesia \\ *E-mail: aulialuqmanaziz@ub.ac.id
}

\begin{abstract}
This study aims to explain the simultaneous Influence of organizational culture level artifacts, organizational culture level values, organizational culture level of basic assumptions on employee performance, to explain the partial influence of organizational culture level artifacts on employee performance, partial influence of organizational culture level of values to employee performance, and to explain the partial influence of organizational culture on the level of basic assumptions on performance. This research was conducted at PT. Bank Negara Indonesia (Persero), Tbk. Malang Branch Office, PG Lestari, Jl. General Basuki Rahmat no 75-77, Kauman, Klojen, Malang City. This research is explanatory research with quantitative approach. The population in this research amounted to 130 employees. The samples used in this research totalled 57 employees. The results of this study indicate that organizational culture level artifacts, organizational culture level of values, organizational culture level of basic assumptions significantly affect employee performance. Partially, organizational culture variable of artifact level has no significant effect on employee performance. Partially, organizational culture variable of level of values influences to employee performance. Partially, organizational culture variable of basic assumption level influences to employee performance.
\end{abstract}

\section{KEY WORDS}

Organizational Culture, Performance, Employee Performance.

The success of a company in achieving its goal is closely related with the quality of its employee performance so that an organization is required to always enhance and improve the performance of its employees. According to Mangkunegara (2005), "Performance is the result of work in quality and quantity achieved by an employee in performing its duties in accordance with the responsibilities given to her/him". In human resources empowerment, it needs a standard reference to be used by the organization to generate professional employees with high integrity. What is meant by standard reference is the organizational culture that systematically helps employees to increase its performance in the organization. By standardizing the organizational culture as a reference in the formulation of rules and regulations, the leader and employees are indirectly attached to each other so that it will form a behavior and attitude that complies the vision, mission, and goals of the organization.

Robins (1996, in Tika, 2011) said that "Organizational culture is a set of systems or values approved and made by all of its members which can distinguish one organization with another organization". Every organization has its own culture in which is different from other organizations thus distinguish them. In Indonesia, the organizational culture was introduced in the era of 1990 when there were a lot of discussions concerning cultural conflicts that is how to maintain the culture of Indonesia as well as the culture of new values (Moeldjono, 2005).

Organizational culture is strongly associated with employee performance. Deal and Kennedy (1982, in Wibisono, 2011) wrote that "To create a high-performance organization, such an integrated and strong culture is needed to produce great results." On the other hand, Moeldjono (2003) argued that "The role of organizational culture is essential for performance improvement. Strong organizational culture will help the organization assures the employees to grow and develop together." 
Organizational culture will ease the employees to adapt with the work environment and allows them to know the dos and don'ts according to the organizational values as well as to uphold the values as a guide to behave. The comprehension of organizational culture must be applied since the beginning of becoming the member of an organization. When they first accepted by the organization, they hold different characteristics and expectations so that through training, orientation, and adjustment, employees will absorb and understand the organizational culture which will develop into a personal culture. If the internalization process of organizational culture to become a personal culture succeed, employees will feel identical with the organization making them feel as part of the organization and there will be no obstacles to achieve optimal performance.

Every organization, either GOs (Governmental Organizations) or NGOs (Nongovernmental Organizations), should have an organizational culture because it is a vital element that must be owned by an organization to achieve its goal. This also applies to the banking industry that in order to maintain its existence amidst the high competition, the bank is demanded to always provide a good service to customers.

One of the organizations that use organizational culture to improve its employee performance is PT. Bank Negara Indonesia (Persero), Tbk or known as BNI. BNI is an Indonesian State-owned Enterprise established since 1946 and has been using organizational culture for a long time. In 1986, BNI proposed its first organizational culture called as Lima Pilar (Five Pillars). Since then, BNI has revitalized its organizational culture several times. The issuance of regulation concerning the implementation of Good Corporate Governance (GCG) by Bank Indonesia on October $5^{\text {th }}, 2006$ that one of which is to create an organizational culture made BNI to change its organizational culture which was previously known as "Lima Pilar dan 12 Perilaku Pegawai" to become "PRINSIP 46" on July $5^{\text {th }}, 2006$.

PRINSIP 46 is an acronym of 4 main values and 6 main behavior of BNI members. The word "Prinsip" is an acronym of 4 main values which also means as the truth and basis to think and act. PRINSIP 46 is made to be used as guidance to work and behave for BNI employees. It is a demand for all BNI members which, in this case, are the people who work and serve for BNI either the commissioners, directors or all employees from the lowest to highest levels of organizational structure. This culture contains important values that are shared together in the working activities and used as a guidance to behave with the top management, fellow workers, customers, and external parties. PRINSIP 46 differentiates BNI from other companies, it gives a value to the stakeholders and making it a competitive advantage.

Based on the banking statistic data of Financial Services Authority in 2016, BNI is in the fourth position of the 10 biggest bank in Indonesia seen from the assets in which BNI itself has an asset of IDR 564,85 trillion. BRI is in the first position with an asset up to IDR 964 trillion, followed by Bank Mandiri with an asset of IDR 918,21 trillion, and BCA in the third position with an asset amounted to IDR 662,62 trillion. This indicates that BNI needs to work hard in improving its performance to achieve a better accomplishment. Therefore, an organizational culture is very essential in this matter to improve BNI performance.

Based on the above descriptions, the purpose of this research is to: (1) To explain and test the influence of Organizational Culture Level Artifacts on Employee Performance; (2) To explain and test the influence of Organizational Culture Level Values on Employee Performance; (3) To explain and test the influence of Organizational Culture Level Basic Assumptions on Employee Performance; (4) To explain and test the influence of Organizational Culture Level Artifacts, Organizational Culture Level Values, and Organizational Culture Level Basic Assumptions on Employee Performance.

The researchers expect that this research can be used as a supplemental information and input for the company associated with organizational culture and performance. In addition, this research might also be a benchmark for prior research and preliminary information for such research in the future. 


\section{LITERATURE REVIEW}

Organizational Culture. Organizational culture is the values that are believed and developed in an organization so that it becomes the characteristics of the organization where it guides the behavior of the organization members itself. Robbins (2002) said that "Organizational culture refers to a system of shared understanding held by the members of the organization; distinguished it from other organizations." Moeljono (2005) also asserted that "In general, organizational culture is a philosophical statement functioned as a demand that holds the employees because it can be formulated formally in any laws and regulations of an organization. Meanwhile, Mangkunegara (2005) acknowledged that "Organizational culture is a set of assumptions or belief systems, values, and norms developed and used as a guidance to behave by the members of the organization to resolve the problems of external adaptation and internal integration".

Schein (1991, in Tika, 2011) wrote that organizational culture is classified into three levels, namely:

Artifacts Level. Artifacts include all phenomena that can be seen, heard, and perceived. This stage is the most visible dimension in organizational culture because the construction is done in the physical environment and social organization. At this level, the people who enter an organization can see the building, output, technology, written and oral language, artistic products, and the real behavior of the organization members clearly. These include its fashion or styles, emotional appearances, myths and organizational histories, as well as values emerging in the communication system such as rituals, ceremonies, and so on. The members of the organization are often unaware of their organizational cultural artifacts while the outsiders can observe them explicitly.

Values Level. As a second level, values are solutions that emerge from a leader in the organization meant to solve the problems that often occur within the organization. If a group has to deal with an important task or organizational problems and issues, the first solution will come from the dominant or influential individuals in the group. They can interpret, assume, and provide an assessment of the problem and will provide solutions in the form of knowledge, attitudes, and actions that are mandatory to be performed. It is assumed that the values are able to reflect the organization's philosophy, mission, objectives, standards, and restrictions. These solutions can run on an ongoing basis and become part of the organizational culture.

Basic Assumptions Level. Basic assumptions are a major part of organizational culture. It is a guarantee that someone found a little variation in the cultural unit. In basic assumptions, there are instructions that the organizational members must obey. This is in concern with real behaviors including explaining to group members how to feel and think about everything. In this case, the things included in basic assumptions are the nature of the relationship with the environment, the nature of time orientation, the nature of humankind, the nature of human activity, and the nature of human relations. The solutions to these basic assumptions are intended to solve the problems on an ongoing basis and can be continuously communicated to be reliable values. These solutions are needed to be used as realities in the organization and are believed to be true so that it can become a compulsory organizational culture.

Performance. In accordance with Rivai \& Basri (2005, in Riani, 2011) performance is "The outcomes from a person as a whole during a certain period in carrying out tasks such as work standards, targets, or criteria that have been determined and mutually agreed in advance." Robbins (2001, in Riani, 2011) also added that "Performance is the number of efforts carried out by individuals on his/her work." meanwhile, according to Tika (2011), "Performance is the result of work function/activity of a person or a group in an organization that is influenced by various factors to achieve organizational goals within a certain period of time".

On the other hand, Dharma (1985) said that the assessment indicators of work performance are as follows: 
Quantity. In this case, quantity is the number of jobs that employees must produce. Quantitative measurement involves the calculation of outputs from the process or implementation of the activity. This is in relation to the number of outputs produced.

Quality. This is in concern with the quality of work from the employees. Qualitative measurement will reflect the satisfaction level which is the grade of the results or outcomes. It is associated with the quality of works produced.

Punctuality. What is meant by punctuality is the suitability between work completion and the planned time. Punctuality measurement is a special type of quantitative measurement that determines the timeliness of completion of an activity.

Based on the theory of organizational culture and performance that has been described above, the hypothesis framework model can be seen below:

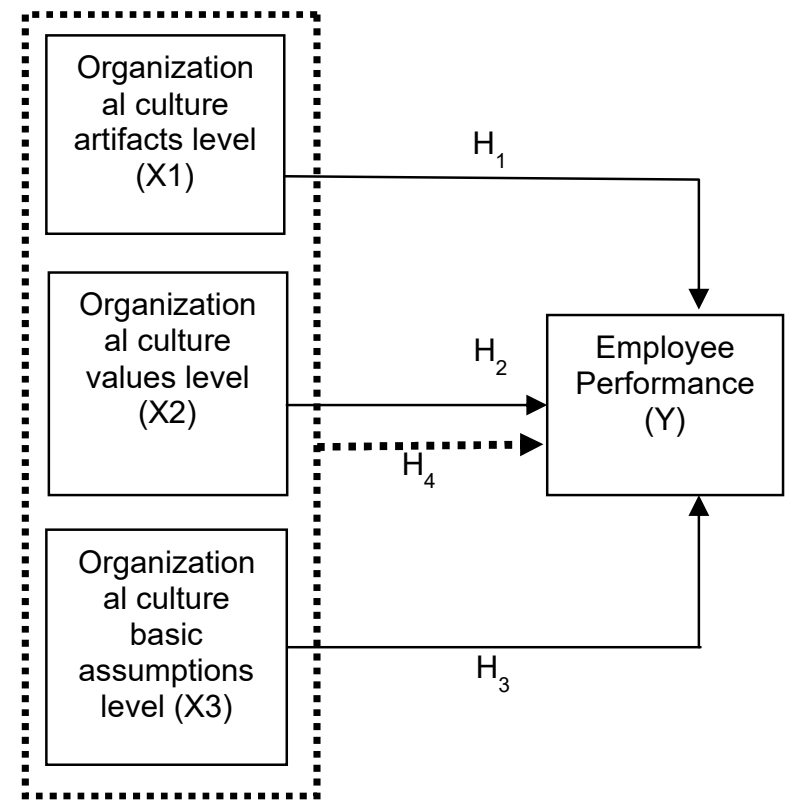

Figure 1 - Hypothesis Model

$\mathrm{H} 1$ : It is presumed that there is a significant influence of Organizational Culture Artifacts Level on Employee Performance.

$\mathrm{H} 2$ : It is presumed that there is a significant influence of Organizational Culture Values Level on Employee Performance.

H3: It is presumed that there is a significant influence of Organizational Culture Basic Assumptions Level on Employee Performance.

$\mathrm{H} 4$ : It is presumed that there is a significant influence of Organizational Culture Artifacts Level, Organizational Culture Values Level, and Organizational Culture Basic Assumptions Level on Employee Performance.

\section{METHODS OF RESEARCH}

This research is a explanatory research with quantitative approach. The research was carried out at BNI Malang Branch Office, Jalan Jenderal Basuki Rahmat Number 75-77, Kauman, Klojen, Malang City, East Java. This location was chosen based on the researchers' consideration that this company owns and applies such an organizational culture that is interesting to be assessed on how far it affects the performance of the employees. The sample was obtained with a non-probability sampling method and a convenience sampling technique. The calculation of the data was done with slovin formula and obtained 57 respondents. The data collection was performed with questionnaires analyzed by using descriptive analysis, multiple linear regression analysis, coefficient determination test, t-test, and f-test. 
Eurasia: Economics \& Business, 7(13), July 2018

DOI https://doi.org/10.18551/econeurasia.2018-07

\section{RESULTS AND DISCUSSION}

Table 1 - The results of multiple linear regression analysis

\begin{tabular}{|c|l|c|c|c|c|c|}
\hline \multicolumn{1}{|c|}{$\mathrm{n} / \mathrm{n}$} & B & Std. Error & Beta & T & Sig \\
\hline \multirow{4}{*}{1} & (Constant) & 6.683 & 5.481 & & 1.219 & .228 \\
\cline { 2 - 6 } & Organizational Culture Artifacts Level & -.140 & .219 & -.115 & -.640 & .525 \\
\cline { 2 - 7 } & Organizational Culture Values Level & .537 & .228 & .371 & 2.354 & .022 \\
\cline { 2 - 7 } & Organizational Culture Basic Assumptions Level & .523 & .211 & .429 & 2.485 & .016 \\
\hline
\end{tabular}

Source: Processed Primary Data, 2018.

Table 2 - Coefficient Determination

\begin{tabular}{|c|c|c|c|c|}
\hline Model & $\mathrm{R}$ & $\mathrm{R}$ Square & Adjusted R Square & Std. Error of the Estimate \\
\hline 1 & $.645^{\mathrm{a}}$ & .416 & .383 & 2.721 \\
\hline
\end{tabular}

Source: Processed Primary Data, 2018.

Table 3 - F-test Results

\begin{tabular}{|l|c|c|c|c|c|}
\hline \multicolumn{1}{|c|}{ Model } & Sum of Squares & Df & Mean Square & F & Sig. \\
\hline Regression & 280.057 & 3 & 93.352 & 12.605 & 0.000 \\
\hline Residual & 392.505 & 53 & 7.406 & & \\
\hline Total & 672.561 & 56 & & & \\
\hline
\end{tabular}

Source: Processed Primary Data, 2018.

Table 4 - T-test Results

\begin{tabular}{|l|c|c|c|}
\hline \multicolumn{1}{|c|}{ Variable } & t-count & t-table & Sig. \\
\hline Organizational Culture Artifacts Level & -0.640 & 2.0058 & 0.525 \\
\hline Organizational Culture Values Level & 2.354 & 2.0058 & 0.022 \\
\hline Organizational Culture Basic Assumptions Level & 2.485 & 2.0058 & 0.016 \\
\hline
\end{tabular}

Source: Processed Primary Data, 2018.

The Variable of Organizational Culture Artifacts Level (X1). Based on the descriptive analysis conducted with frequency distribution, the variable of Organizational Culture Artifacts Level has a grand mean that is 4.23. This means that BNI Malang Branch Office has a very good Organizational Culture Artifacts Level. The highest average for the variable of Organizational Culture Artifacts Level is found on the second item $\left(X_{1.2}\right)$ that is 4.51 in regard to the assumption that a pleasant work environment can improve employee performance. Whereas, the lowest average for the variable of Organizational Culture Artifacts Level (X1) lies on the fourth item $\left(X_{1.4}\right)$ that is 4.09 . This is in concern with the assumption that the organization already provided such an adequate facility to support the employee.

The Variable of Organizational Culture Values Level (X2). Based on the descriptive analysis carried out by using frequency distribution, the variable of Organizational Culture Values Level has a grand mean of 4.30. This indicates that BNI Malang Branch Office has a very good grade of Organizational Culture Values Level. The highest average for the variable of Organizational Culture Values Level is on the second item (X2.2) by 4.40 that the employees do the work based on the vision, mission, and goals of the organization. Meanwhile, the lowest average for the variable of Organizational Culture Values Level is found on the third item (X2.3) that is 4.21 referring to the assumption that the organization has applied and socialized the organization rules well to all employees.

The Variable of Organizational Culture Basic Assumptions Level (X3). Based on the descriptive analysis performed with frequency distribution, the variable of Organizational Culture Basic Assumptions Level has a grand mean of 4.17. It shows that BNI Malang Branch Office has a good Organizational Culture Basic Assumptions Level. The highest average for the variable of Organizational Culture Values Level is on the ninth item (X3.9) that is 4.26. This is in concern with the assumption that the employees have a good relationship with other fellow employees. On the other hand, the lowest average for the 
variable of Organizational Culture Values Level can be found on the fourth item (X3.4) that is 4.09 that the loyal employees provide time for the organization.

The Variable of Employee Performance (Y). Based on the descriptive analysis and frequency distribution, the variable of Employee Performance has a grand mean of 4.12. This means that BNI Malang Branch Office has a good Employee Performance. The highest average for the variable of Employee Performance is on the second item (Y1.1) by 4.32 that the employees can complete the work in accordance with the standard quantity in the organization. In comparison, the lowest average for the variable of Employee Performance lies on the ninth item (Y1.9) that is 3.91 in regard to the assumption that the employees can complete the work faster than other employees.

The Influence of Organizational Culture Artifacts Level on Employee Performance. From the results of analysis and hypothesis test, it can be known that, partially, the Organizational Culture Artifacts Level consisting of three indicators such as work environment, technology and facility, and appearance (Schein 1991 in Tika, 2011:22-23) does not have a significant influence on the employee performance of BNI Malang Branch Office. This result is in accordance with the hypothesis test carried out through t-test generating a t-count as much as -0.640 and $t$-table by 2.0058 as well as significance value by 0.525 that is greater than $\alpha(0.005)$. Therefore, it can be concluded that, partially, the Organizational Culture Artifacts Level (X1) does not have a significant influence on Employee Performance $(Y)$.

The Influence of Organizational Culture Values Level on Employee Performance. Based on the results of analysis and hypothesis test, it is revealed that, partially, Organizational Culture Values Level consisting of three indicators such as vision, mission, goals, and work standards of the organization (Schein 1991 in Tika, 2011:22-23) does not influence employee performance at BNI Malang Branch Office significantly. This result is obtained based on the hypothesis test that is done with t-test in which producing a t-value as much as 2.354, t-table as much as 2.0058, and significance value as much as 0.22 that is greater than the value of a (0.05). This means that, partially, Organizational Culture Values Level (X2) does not significantly affect Employee Performance (Y).

The Influence of Organizational Culture Basic Assumptions Level on Employee Performance. Based on the results of analysis and hypothesis test, it is known that, partially, Organizational Culture Basic Assumptions Level consisting of five indicators such as the nature of the relationship with environment, the nature of time orientation, the nature of humankind, the nature of human activity, and the nature of human relations (Schein 1991 in Tika, 2011:22-23) significantly influences the employee performance on BNI Malang Branch Office. It is obtained from the hypothesis test conducted through t-test that generates a tvalue of 2.458 and t-table by 2.0058 as well as significance value by 0.16 that is greater than a (0.05). It is certain that, partially, Organizational Culture Basic Assumptions Level (X3) influences Employee Performance (Y) significantly.

The Simultaneous Influence of Organizational Culture Artifacts Level, Organizational Culture Values Level, and Organizational Culture Basic Assumptions Level on Employee Performance. Based on the results of analysis and hypothesis test, it is noted that Organizational Culture Artifacts Level (X1), Organizational Culture Values Level (X2), and Organizational Culture Basic Assumptions Level (X3) have a simultaneous influence on Employee Performance $(\mathrm{Y})$ at BNI Malang Branch Office. This result is acquired from the hypothesis test and F-test generating F-table as much as 2.78. On the other hand, it is known that the value of $F_{\text {count }}>F_{\text {table }}$ is $12.605>2.78$ and $F$ significance by $(0.000)<\alpha(0.05)$. Therefore, it can be said that Organizational Culture Artifacts Level (X1), Organizational Culture Values Level (X2), and Organizational Culture Basic Assumptions Level (X3) have a simultaneous influence on Employee Performance $(Y)$. In addition, from the R-square, the variable of organizational culture artifacts level, organizational culture values level, and organizational culture basic assumptions level give an effect or contribution to the variable of employee performance as much as $0.416(41.6 \%)$ while the rest of it is influenced by other variables that are not mentioned in this research. 


\section{CONCLUSION}

There are several conclusions derived from the results of this study, such as:

From the descriptive analysis, it is obvious that the variable of Organizational Culture Artifacts Level (X1) has a grand mean that is 4.23. This means that BNI Malang Branch Office has a very good Organizational Culture Artifacts Level. While from the partial analysis, it is known that Organizational Culture Artifacts Level (X1) does not have a significant influence on Employee Performance $(Y)$. It is proved with a $t_{\text {count }}$ that is $-0.640<t_{\text {table }}$ that is 2.0058 and the value of sig-t by $0.525>\alpha=0.05$ so that it can be concluded that Employee Performance $(\mathrm{Y})$ is not affected significantly by Organizational Culture Artifacts Level (X1). In other words, with the increasing Organizational Culture Artifacts Level (X1), the performance of the employee $(Y)$ will not be improved significantly.

Based on the descriptive analysis, the variable of Organizational Culture Values Level (X2) has a grand mean that is 4.30. It shows that BNI Malang Branch Office has a very good Organizational Culture Values Level. Seen from the partial analysis, the Organizational Culture Values Level (X2) has a significant influence on Employee Performance (Y). This is supported with the value of $t_{\text {count }}$ by $2.354>t_{\text {table }}$ by 2.0058 and the value of sig-t by $0.022<\alpha$ $=0.05$. Therefore, it can be said that Employee Performance $(Y)$ is influenced significantly by Organizational Culture Values Level $(\mathrm{X} 2)$ or in other words, with the increasing Organizational Culture Values Level (X2), the Employee Performance (Y) will also be increased.

Based on the descriptive analysis, the variable of Organizational Culture Basic Assumptions Level (X3) has a grand mean of 4.17. This implies that BNI Malang Branch Office has a good Organizational Culture Basic Assumptions Level. Meanwhile, the partial analysis shows that, partially, Organizational Culture Basic Assumptions Level (X3) has a significant influence on Employee Performance $(\mathrm{Y})$. This is indicated by $t_{\text {count }}$ as much as $2.485>t_{\text {table }}$ as much as 2.0058 and sig-t by $0.16<\alpha=0.05$. By that, this indicates that Employee Performance $(\mathrm{Y})$ is affected significantly by the variable of Organizational Culture Basic Assumptions Level (X3). With the increasing Organizational Culture Basic Assumptions Level (X3), Employee Performance (Y) will also have a visible improvement.

Organizational Culture Artifacts Level (X1), Organizational Culture Values Level (X2), and Organizational Culture Basic Assumptions Level (X3) are known to simultaneously influence Employee Performance $(\mathrm{Y})$. This is supported with the value of $\mathrm{F}_{\text {count }}$ by $12.605>$ $F_{\text {table }}$ by 2.78 and probability value by 0.000 . The $R^{2}$ value on this research is 0.416 or $41.6 \%$ while the rest of it is influenced by other variables that are not mentioned in this research.

Based on the results of the research, there are some suggestions described as follows:

On the variable of Organizational Culture Artifacts Level, the lowest average lies on the fourth item (X1.4) that is 4.09 concerning the assumption that the organization already provided such an adequate facility to support the employee. Therefore, it is expected that the company will improve the technology and facility to support the work of the employee so that they can produce better performance.

On the variable of Organizational Culture Values Level, the lowest average is found on the third item (X2.3) that is 4.21. This refers to the assumption that the organization has applied and socialized the organization rules to all employees. By that, the company is expected to give a better understanding and socialization in concern with organization rules to all employees.

On the variable of Organizational Culture Basic Assumptions Level, the lowest average is on the fourth item (X3.4) that is 4.09. It is assumed that the loyal employees provide time for the company with pleasure so that the company is expected to approach its employees better. This will make the employees be more loyal to the organization.

It is expected that the company can analyze and look closely the factors underlying the Organizational Culture Artifacts Level (X1) among others work environment, technology, facility, and appearance which have a contrast relationship with Employee Performance $(Y)$. Thus, BNI Malang Branch Office can do a setup and improvement for this matter in which as a result, Organizational Culture Artifacts Level (X1) can improve Employee Performance (Y). 
It is expected that the company is able to maintain and improve the quality of things which are part of the Organizational Culture Values Level (X2) such as vision, mission, goals, regulations, and work standard of the organization so that it can improve the employee performance $(\mathrm{Y})$ on an ongoing basis.

The company is expected to maintain and increase the things that become part of the Organizational Culture Basic Assumptions Level (X3) such as the relationship with the environment, time orientation, human nature, human activity, and human relation so that it can continuously improve the Employee Performance (Y).

\section{REFERENCES}

1. BNI. (2017). Budaya Perusahaan. Retrieved from http://bni.co.id/idid/perusahaan/tentangbni/budayaperusahaan on December 20, 2017.

2. Mangkunegara, A. P. (2005). Perilaku Dan Budaya Organisasi. Bandung: Rafika Aditama.

3. Moeldjono, D. (2003). Budaya Korporat dan Keunggulan Korporasi. Jakarta: PT Elex Media Komputindo.

4. Moeldjono, D. (2005). Cultured! Budaya Organisasi Dalam Tantangan. Jakarta: PT Elex Media Komputindo.

5. Robbins, S. P. (2002). Perilaku Organisasi: Konsep, Kontrovensi, dan Aplikasi. Jakarta: Erlangga.

6. Kompas Online. (2018). Saling Salip Bank Papan Atas. Retrieved from http://ekonomi.kompas/read/2017/03/23/082400326/saling.salip.bank.papan.atas on March 20, 2018.

7. Tika, M. P. (2011). Budaya Organisasi dan Peningkatan Kinerja Karyawan. Jakarta: Bumi Aksara.

8. Wibisono, D. (2011). Manajemen Kinerja Korporasi \& Organisasi. Jakarta: Penerbit Erlangga Jakarta. 